\title{
The Function and Fate of the Cystidia of Coprinus atramentarius, together with some General Remarks on Coprinus Fruit-bodies.
}

\author{
BY
}

\author{
A. H. R. BUlleR, D.Sc., Ph.D., F.R.S.C. \\ Professor of Botany at the University of Manitoba.
}

\section{With Plates $\mathrm{L}$ and LI.}

\section{Contents.}

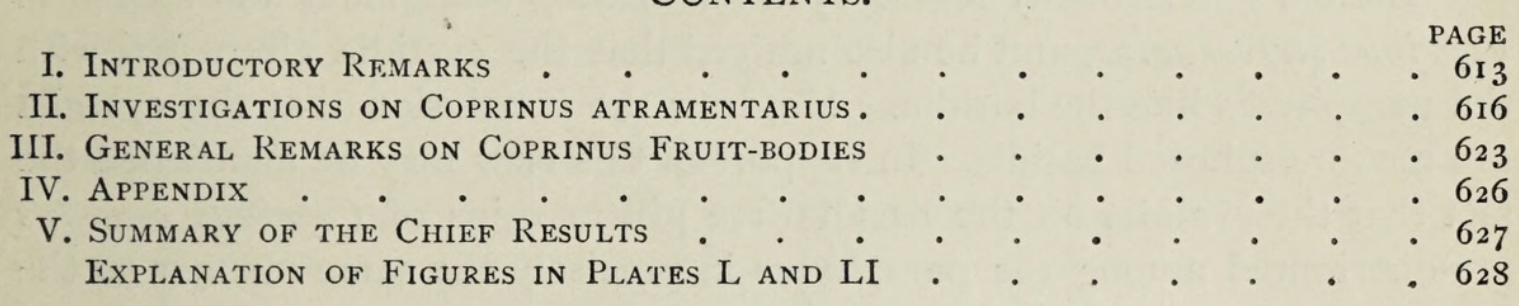

I. INTRODUCTORY REMARKS.

CYSTIDIA are certain specialized cells, usually much larger than the paraphyses and basidia, of peculiar shape, which form part of, and project from, the hymenium of certain species of Hymenomycetes and Gastromycetes.

The form and size of cystidia vary much in different species, but for any one species they are fairly constant. Cystidia are unbranched and as a rule unicellular, but in the two species of the genus Bonia ${ }^{1}$ they are represented by numerous short multicellular bristles. Cystidia may be cylindrical as in Coprinus atramentarius, fusiform as in Peniophora quercina, ${ }^{2}$ ventricose as in Inocybe geophylla, ${ }^{3}$ spear-shaped as in Hymenochaete Cacao, ${ }^{4}$ or club-shaped as in Polyporus mollis. ${ }^{5}$ The wall of the part of a cystidium which is exposed to the air may remain smooth as in the Coprini, or it may become covered with crystals of calcium oxalate as in species of Peniophora, ${ }^{6}$ or it may become crowned with mucilage as in Inocybe geophylla. ${ }^{7}$

1 Engler und Prantl, Die nat. Pflanzenfamilien, Teil I, Abteil. I**, p. I23.

2 Ibid., Fig. 68 B, p. 122.

${ }^{3}$ G. Massee, A monograph of the genus Inocybe. Annals of Botany, vol. xviii, 1904, p. 477 and Pl. XXXII, Figs. 7,8 , and 9 .

${ }^{4}$ Engler und Prantl, l. c., Fig. 68 E, p. 122.

${ }_{5}$ R. Hartig, Die Zersetzungserscheinungen des Holzes, Berlin, I878, p. 5 I, also Taf. IX, Fig. 10.

6 M. C. Cooke, Introduction to the Study of Fungi, 1895, p. I43.

7 G. Massee, 1. c., p. 463 and Pl. XXXII, Figs. 7 and 8.

Annals of Botany, Vol. XXIV. No. XCVI. October, 1910.] 
The distribution of cystidia among species and genera is very irregular. Thus for instance, in the Thelephoreae, whilst cystidia are present in the genera Peniophora and Hymenochaete, they are absent in Corticium, Stereum, Coniophora, and Craterellus. ${ }^{1}$ But in a single genus some species may possess cystidia, and others not. Thus Psathyra spadiceo-grisea ${ }^{2}$ and Fomes nigricans ${ }^{3}$ are provided with cystidia, whereas Psathyra nolitangere ${ }^{4}$ and Fomes annosus ${ }^{5}$ are without them. Even in closely allied species which have cystidia, the distribution of these structures may differ considerably. Thus in Coprinus comatus the cystidia are restricted to the free margins of the gills, whilst in C. atramentarius they are not only present in these situations but project in large numbers from the general hymenial surfaces. Cystidia occur in species of the Hymenogastrineae, ${ }^{6}$ but, so far as I am aware, they have not been found in any other group of Gastromycetes.

Brefeld ${ }^{7}$ occasionally found cystidia bearing sterigmata and spores in Coprinus stercorarius, and he also noticed that the cystidia alternated with the paraphyses like the basidia. He drew the conclusion that the cystidia are metamorphosed basidia. In support of this view may be mentioned the fact that the cystidia on the basidia-free gill-margins of Coprinus comatus are distributed among the paraphyses in precisely the same manner as the basidia on the general gill-surfaces. ${ }^{8}$

The different types of cystidia are so diverse in size, structure, and distribution that it seems certain that they cannot all have the same function. Cystidia are analogous to the epidermal hairs of the higher plants, and probably like these they perform various functions for which they are fitted by their peculiar structure. So far, however, comprehensive physiological studies of these functions have not been made, so that we are still almost entirely in the dark as to what they are and what part they play in the fruit-body economy.

A few decades ago it was thought that cystidia were male organs. This view was held by Corda, Hoffmann, ${ }^{9}$ and Worthington Smith. ${ }^{10}$ The last-named writer thought that the cystidia were antheridia which produced spermatozoa. He believed that the spermatozoa found their way to the spores with which they fused, thus bringing about their fertilization.

Earlier writers, Corda and others, stated that the cystidia of fleshy Fungi discharge their contents through their apices in the form of drops, but

1 Engler und Prantl, 1.c., pp. II 7 and I 18.

${ }^{2}$ O. Brefeld, Untersuchungen, Heft 8, p. 47.

${ }^{3}$ G. Massee, British Fungus-Flora, vol. i, p. 22 I.

4 O. Brefeld, l. c, p. 48.

${ }^{6}$ Engler und Prantl, l. c., p. 29 , also Fig. I $50 \mathrm{E}$.

${ }^{7}$ O. Brefeld, Untersuchungen, Heft 3, p. 54.

8 A. H. R. Buller, Researches on Fungi, London, I909, Pl. III, Fig. 13.

9 H. Hoffmann, Die Pollinarien und Spermatien von Agaricus. Bot. Zeit., Bd. xiv, pp. I37-8, $153-63$.

${ }^{10}$ W. Smith, Reproduction in Coprinus radiatus. Grevillea, vol. iv, 1875-6, pp. 53-63. 
De Bary ${ }^{1}$ states that both he and Brefeld could never satisfy themselves that this is done spontaneously. However, Massee ${ }^{2}$ has upheld the older view. In one of his first papers he stated that cystidia, when mature, contain glycogen, which is emitted through the nipple-like openings at their apices and poured over the surrounding hymenium, where it serves as food. In his recent monograph on Inocybe, he ${ }^{3}$ states that in this genus the cystidia become crowned with mucilage, which escapes from the interior after the deliquescence of the thin portion of the walls at their apices.

Massee ${ }^{4}$ remarks that in Peniophora 'the cystidia are colourless, thinwalled, and eventually become rigid, due to a superficial crust of particles of lime. When young the cystidia appear to act as organs of transpiration; very minute drops of water containing the lime salt in solution are liberated by the cystidia, and as the water evaporates, the lime is deposited as a superficial crust. In Hymenochaete the cystidia are brown in colour, thickwalled, and not at all encrusted with lime.' From these observations it seems not unlikely that in some cases at least cystidia have excretory functions comparable with those of certain epidermal hairs of flowering plants ; but we shall see that such functions cannot possibly be attributed to the cystidia of Coprinus atramentarius.

Worthington Smith, ${ }^{5}$ twenty-nine years ago, figured the cystidia of Coprimus atramentarius, Gomphidius viscosus, and Agaricus radicatus as large flask-like structures with narrow necks, each provided with an operculum. He stated that the opercula drop off when the cystidia are mature, and thus permit the cell-contents to escape. It will become evident from what follows that these observations, in so far as they concern Coprimus atramentarius, were in the main erroneous.

The best suggestion for the function of the large cystidia which occur on the gill-surfaces of many Coprini was made by Brefeld. ${ }^{6}$ In his masterly account of the life-history of Coprinus stercorarius, he recorded the observation that during the development of the gills the cystidia grow towards the neighbouring gills and often press into them; and he adds: 'Man möchte fast glauben, als ob sie dazu dienten, die Lamellen in gemessener Entfernung von einander zu halten, damit sie mit der Streckung, während welcher die Sporenbildung vor sich geht, sich nicht stören und gegenseitig bedrücken.' He further remarks: 'Der Gedanke, dass die Cystidien seitliche Schutzpfosten sind, deren Gestalt sie nachahmen, könnte vielleicht noch darin eine Stütze finden, dass die kürzeren Lamellen an ihrer Spitze keine Cystidien ausbilden wie die grossen, die bis zum Stiel reichen.' From

1 De Bary, Comparative Morph. and Biol. of Fungi, 1887, p. 304 .

2 G. Massee, Journ. Roy. Micr. Soc., I887, p. 205.

3 G. Massee, A Monograph of the genus Inocybe. Ann. of Bot., vol. xviii, I904, p. 462 .

4 G. Massee, A Textbook of Fungi, London, I906, p. 350.

5 W. Smith, Grevillea, vol. x, I88r, p. 304 ; also Gardeners' Chronicle, 188r, p. 367 .

- O. Brefeld, Untersuchungen, Heft 3,1887, pp. 57 and $5^{8}$. 
these quotations it is evident that Brefeld regarded his suggestion as tentative, and that he did not feel justified in laying much emphasis upon it. Notwithstanding the fullness of his illustrations, he did not show cystidia stretching between the gills; nor did he say anything about their ultimate fate.

In the present paper I hope to prove that the cystidia of Coprinus atramentarius do actually serve the purpose suggested by Brefeld. I shall further endeavour to explain why the gills should be kept a certain distance apart, and finally, how the cystidia are got rid of, when by their presence they would constitute a hindrance to the escape of the spores from between the gills. A study of the comparative anatomy of C. atramentarius and C. comatus will enable us to understand why cystidia should be present on the general gill-surfaces of the former species and absent from those situations in the latter.

In a recent publication $\mathrm{I}^{1}$ have given a somewhat detailed account of the beautiful mechanism of the fruit-body of Coprinus comatus. It was shown that the spores ripen on the gills from below upwards, and that there is a zone of spore-discharge that passes from the bottom to the top of each gill in the course of about forty-eight hours. It was further shown that 'deliquescence' is a process of auto-digestion that serves to remove those parts of the gills which have already shed their spores and which, if they continued in existence, would hinder the fall of the remaining spores. I stated that the arrangements for spore-liberation in Comatus atramentarius were essentially the same as those in Coprinus comatus. ${ }^{2}$ Whilst this statement is true, we shall see that the presence of the cystidia on the general surfaces of the gills in the former species and their absence in the latter are associated with some very interesting differences in detail in the respective fruit-body mechanisms. In order to explain the function of the cystidia of Coprinus atramentarius, it will be necessary to describe the general structure of the fruit-body and the mode of spore-liberation.

\section{Investigations on Coprinus atramentarius.}

Coprinus atramentarius is one of the largest and commonest species of its genus. It is widely distributed over the earth's surface, and has been found in Europe, North America, Australia, and Kerguelen Island. ${ }^{3}$ The genus Coprinus, according to Hennings, ${ }^{4}$ contains about 175 species. Whilst most of them grow on dung or dunged ground, a few occur on dead stems or wood. Coprinus atramentarius belongs to the minority, and,

1 A. H. R. Buller, Researches on Fungi, London, 1909, part i, chap. xix. The Coprinus Type of Fruit-body, pp. 196-2I 5 .

${ }^{2}$ Ibid., p. 208.

3 G. Massee, A Revision of the genus Coprinus. Ann. of Bot., vol. x, 1896, p. 143 .

${ }^{4}$ P. Hennings, in Engler u. Prantl, Die nat. Pflanzenfamilien, Teil I, Abteil. I**, p. 205. 
so far as my observation has gone, is most frequently found on partly buried stumps and logs of wood. In England I have often noticed the fruit-bodies at the foot of gate-posts and the supports of fence-rails. Probably the mycelium is specialized for the destruction of wood.

The fruit-bodies of Coprinus atramentarius are usually clustered, four or more individuals often being united by the bases of their stipes. The pilei are silvery grey, ashen grey, or sometimes brownish in colour. ${ }^{1}$ They are usually more or less scaly, frequently plicate or lobed, and at first eggshaped, although later on during auto-digestion they become expanded (Pl. L, Figs. I-4). The gills are exceedingly thin, and at the same time very broad; they are somewhat less than $0.2 \mathrm{~mm}$. thick and often 10 or I $2 \mathrm{~mm}$. wide. On account of their thinness and breadth they are mechanically remarkably weak, and in this respect differ much from the gills of the Mushroom and of fruit-bodies of the same type. When two gills are torn apart, the cystidia can be seen with the naked eye as pellucid processes projecting in large numbers from the hymenial surfaces.

If a median cross-section be taken through the gills (i. e. in the direction $c-d$ in Pl. L, Fig. I), the cystidia can readily be made out, extending across the interlamellar spaces. They present the appearance shown in PI. L, Fig. 5. A thin cross-section more highly magnified (Pl. L, Fig. 8) shows that each cystidium consists of a single large cylindrical cell which has a narrowed end inserted in the hymenium from which it has originated, and a rounded apex which has come to be partly embedded in the hymenium of the opposing gill. The connexion of the cystidia with more or less cylindrical subhymenial cells can often be made out (cf. Pl. L, Figs. 8, 9, IO, and II). There can be no doubt that the apical end of each cystidium becomes fixed into the hymenium against which it has come to press. This is proved by the fact that when the gills are mature, one cannot pull any adjacent two apart without tearing them. The cystidia hold the gills tightly bound together. When one succeeds in forcibly separating parts of two neighbouring gills, one finds that although the cystidia have mostly separated from one of the gills at their apical ends, and have thus remained attached to the other gill by their basal ends (Pl. LI, Fig. I9, $i$ ), not infrequently the reverse happens ; the cystidia which have broken away at their basal ends and have remained attached at their apical ends then have the appearance shown in Pl. LI, Fig. I 9, $j$. Worthington Smith ${ }^{2}$ doubtless saw cystidia projecting in this manner, for his figure shows one upside down. $\mathrm{He}$ evidently thought that the narrowed end of each cystidium was the apical end, and that it projected freely into the interlamellar space. It may well have been this error which suggested to him that a cystidium is really

${ }^{1}$ Cf. G. F. Atkinson, Studies of American Fungi. Ithaca, Igor, p. 40. Some excellent photographs of Coprinus atramentarius are given in his Figs. 39-42.

${ }^{2}$ W. Smith, Cystidia in the Mushroom Tribe. Grevillea, vol. x, I88 r, p. 78. 
like a flask in function, that the wall closing the end of the neck acts as a stopper which drops out when the cystidium is ripe, and that through the neck the cystidium contents escape. His supposed discoveries that the cystidia produce spermatozoa ${ }^{1}$ and fall from the gills with the spores ${ }^{2}$ were simply further errors suggested by his imagination, and involved with his fanciful theory that the cystidia are antheridia, and that their spermatozoa fertilize the spores, which he regarded as female gametes. The reason why the base of a cystidium is narrowed is readily understood, when one remembers that it is necessary for the developing cystidium to retain its connexion with the small subhymenial cells. The general shape of a cystidium is very much like that of a prop, such as one sees used for preventing the collapse of the sides of deep trenches made in the ground. The narrowed end at the base and the blunt rounded end at the apex are well suited to prevent the cystidia from being pushed into the hymenium of either gill by lateral pressure.

The cystidia are some of the largest cells found in connexion with fungi ; they are 0.12 to $0.17 \mathrm{~mm}$. long, and 0.02 to $0.03 \mathrm{~mm}$. wide. Illustrations showing their variations in shape and size are given in Pl. L, Figs. 9, IO, and II. When a cystidium has become mature, it contains a very large central vacuole, and its protoplasm, except for a slight accumulation at each end of the cell, is reduced to a thin lining layer (Pl. LI, Fig. I2). Owing to the limited time during which the living material was available, I was unfortunately prevented from investigating the nature of the cell-sap.

The distribution of the cystidia over the gills is fairly uniform (Pl. L, Fig. 6). It was estimated that about 75 to 100 are situated on each square millimetre of gill-surface. The cystidia are sufficiently numerous to make it impossible for the gills to sag laterally, so that they should come to touch one another with their general surfaces.

The gill-edges are not thickened, and in this are unlike those of Coprimus comatus. They are provided with cystidia which before the expansion of the pileus abut upon the stipe (Pl. L, Figs. 5 and 6).

The basidia are of the usual Coprinus pattern (Pl. L, Figs. 8 and II). They project considerably beyond the paraphyses, and are inserted in the hymenium by narrowed bases. The spores are oval in shape, and very dark brown in colour. The mode in which the basidia are spaced, and the manner in which the spores are situated on the sterigmata, are shown in Pl. L, Figs. 6 and $\mathrm{II}$.

The cells composing the young hymenium are fairly uniform in size, and more or less club-shaped. However, as differentiation proceeds, those cells which are to become basidia elongate in the direction of their long

${ }^{1}$ W. Smith, Reproduction in Coprinus radiatus. Greviliea, vol. iv, 1875 .

${ }^{2}$ W. Smith, Ibid., p. 6o. 'The spores naturally fall to the earth, and with them the cystidia, and it is upon the moist earth that fertilization is generally carried out.' 
axes, whilst those which are to become paraphyses expand laterally. Here, as in the Coprini generally, the paraphyses have at least two functions: (I) they act as spacial agents, in that by their presence they keep the basidia so far apart that the spores of neighbouring basidia cannot come into contact, and (2) by their gradual expansion they help in bringing about the expansion of the pileus. The second of these functions was first noticed by Brefeld ${ }^{1}$ in his studies of Coprinus stercorarius. During the movement of the gills of Coprinus atramentarius from the vertical to the horizontal position (cf. Pl. L, Figs. I-4), not a single cell is added to the hymenium, and probably none to the subhymenium and trama. The elongation of the gill-margins which takes place during this movement seems to be entirely due to the expansion of the cells.

The mode of ripening of the spores and their manner of liberation in Coprimus atramentarius is practically the same as that which I have described for Coprimus comatus. The spores ripen on each gill from below upwards. As they ripen, they gradually turn brown in colour, so that in the mass they look black. Hence it is that the gills turn black at their bases first, and that the blackening progresses upwards on each gill (cf. Pl. L, Figs. I-4).

When the pileus has become expanded to the extent shown in Pl. L, Fig. 1, the process of spore-discharge begins. The first spores to be discharged are those which are situated in a narrow zone which extends along both sides of the extreme lower margin of each gill $(s$ in Pl. L, Fig. 2$)$. The zone of spore-discharge which has thus come into existence then gradually moves upwards on each gill from the bottom to the top. As soon as a narrow zone (somewhat less than $0.25 \mathrm{~mm}$. wide) along the bottom of each gill has become spore-free owing to spore-discharge, the process of autodigestion begins. The cells composing the gills in the spore-free zones break down, become fluid, and disappear. This process, which is known to mycologists as 'deliquescence', I have called auto-digestion, ${ }^{2}$ for there is every reason to suppose by analogy that the gill-tissues are destroyed by enzymes which are liberated from the cell-sap of the dying cells. The zone of auto-digestion which has come into existence in the manner just explained gradually ascends each gill, which thus becomes destroyed from below upwards. The zone of auto-digestion follows hard after the zone of spore-discharge, but never invades it. It simply involves the zone which has become free from spores. After auto-digestion has begun, five zones can be distinguished in succession from above downwards on the surface of each gill within half a millimetre of, and parallel to, its edge : (1) a zone of basidia with ripe spores, (2) a zone of spore-discharge, (3) a zone of sporefree surface, (4) a zone of auto-digestion, and (5) a dark adhesive liquid film

${ }^{1}$ O. Brefeld, Untersuchungen, Heft $3, \mathrm{I} 887, \mathrm{pp} .64$ and $6_{5}$.

2 A. H. R. Buller, Researches on Fungi, p. 200. 
at the gill-edge (P1. L, Fig. 7). These five zones keep their relative distances apart unaltered. They gradually move upwards, so that in the course of about forty-eight hours they involve the whole of each gill (cf. Pl. L, Figs. I-4).

The discharge of the spores from the basidia in Coprinus atramentarius takes place in a manner similar to that which I have described for other Coprini and for the Hymenomycetes generally. The four spores of each basidium are violently propelled more or less perpendicularly outwards from the hymenium into the adjacent interlamellar space. The four spores of each basidium leave the sterigmata one by one, and are not all discharged together. The discharges can easily be watched if one lays a piece of a gill, like that shown in P1. L, Fig. 7, in a closed compressor cell (where it is protected from undue loss of moisture), and looks down upon it from above. The spores can then be seen leaving the basidia in the zone of spore-discharge. Some of the basidia will be seen to have four spores upon them, some three, some two, some one, and some none at all.

In my previous researches $I^{1}$ have shown that the spores of the Mushroom, of Polyporus squamosus, and of Coprimus plicatilis are shot forward in almost a straight line into the interlamellar spaces to a distance of about $0.10 \mathrm{~mm}$., and that the horizontal motion is very rapidly brought to an end owing to the resistance of the air. In still air, in consequence of this resistance and of the attraction of gravitation, a spore, when nearing the end of its horizontal flight, describes a sharp curve and falls vertically downwards. I have called the peculiar trajectory of a spore between the gills the sporabola. ${ }^{2}$ By using methods which have been described in detail elsewhere, I have proved to myself that the spores of Coprimus atramentarius have a trajectory similar to that of Coprinus plicatilis and other Coprini, and that the horizontal distance of discharge is of the order of $0.05 \mathrm{~mm}$. Unfortunately an exact determination of this distance could not be made owing to the limited time during which living fruit-bodies were at my disposal. On the assumption that 0.05 is the average distance of discharge of spores shot out perpendicularly from the hymenium, I have indicated the sporabolas of a few spores in the zone of spore-discharge in the semi-diagrammatic drawing in Pl. LI, Fig. I9. It is certain that the spores are shot forward to such a distance from the basidia that they fall downwards somewhere near the middle of the interlamellar spaces. I have already pointed out that the advantage of violent spore-discharge lies in the fact that thereby the adhesive spores are prevented from coming into contact with one another or with the gill-surfaces during their fall.

The cystidia are so large and numerous that, if they persisted until the zone of auto-digestion reached them, they would form a serious hindrance to the escape of the spores from between the gills. They would block up

${ }^{1}$ A. H. R. Buller, Researches on Fungi, pp. I 4 I and $\mathbf{I}_{4}^{2}$.

${ }^{2}$ Ibid., l. c., p. 185 . 
so large a proportion of the interlamellar spaces that a great many spores would settle upon them, and in that way be prevented from escaping into the outer air. A beautiful arrangement is provided to make this impossible. The cystidia do not undergo auto-digestion at the same time as the basidia and paraphyses in their immediate vicinity, but a short time previously thereto. They destroy themselves in succession from below upwards on each gill, and each one disappears a few minutes before the basidia in its neighbourhood come to be involved within the upwardly progressing zone of sporedischarge. The semi-diagrammatic drawing given in Pl. LI, Fig. I9, shows what was made out by means of sections taken transversely to the gills or parallel to their edges. The section through three gills is supposed to be quite vertical. From above downwards one can distinguish the following seven zones: $(a)$ a zone of less ripe spores in which the cystidia are fully turgid, and are acting as props to keep the gills apart; (b) a zone of riper spores in which the cystidia are disappearing; $(c)$ a zone of ripe spores from which the cystidia have already disappeared; $(d)$ a zone of spore-discharge where cystidia are absent; $(e)$ a spore-free zone ; $(f)$ a zone of auto-digestion; and finally, $(g)$ a liquid film, the products of auto-digestion, at the gill-edge. It is clear that, owing to their early auto-digestion, the cystidia cannot possibly hinder the fall of the spores and their escape from between the gills.

Since the cystidia of Coprimus atramentarius are essential constituents of the fruit-body mechanism in that they alone prevent the very thin, very broad, and very flexible gills from coming into contact with one another, it is not surprising that we should find that they are retained between the gills as long as practicable without their becoming hindrances to the fall of the spores. They are removed only just in time to prevent them ever extending between those parts of the gills where spore-discharge is taking place. The cystidia-freed portions of the gills which hang downwards (Pl. LI, Fig. I 9 , zones $c, d, e, f$, and $g$ ) are only about $0.25 \mathrm{~mm}$. in depth. They are kept apart by means of the cystidia above them, so that there is no danger of the interlamellar spaces between them becoming reduced in width. As a matter of fact the interlamellar spaces in the regions of spore-discharge appeared to be distinctly broadened out owing to a slight contraction of those parts of the gills undergoing auto-digestion (cf. Fig. 19).

The fate of the cystidia was found out by studying sections, about I $\mathrm{mm}$. thick, which were cut transversely through the gills. Some of the sections were cut perpendicularly to the gill-edges and therefore resembled that shown in Pl. L, Fig. 5, whilst others were cut in such a way that one side of each section was made up of the free auto-digesting edges of several gills. In all cases the sections were placed in a compressor cell in order to prevent undue transpiration. Where a section included the free gill-edges, it was turned upside down so that the edges looked upwards. On looking at the sections with the low power of the microscope, it was possible not 
only to see the cystidia stretching across the interlamellar spaces but also to observe their disappearance.

About $0.5 \mathrm{~mm}$. above the extreme edge of each gill where the liquid products of auto-digestion are adhering, the cystidia can be seen in the first stages of their disappearance. This is indicated by a slight diminution in their diameters. Nearer to the auto-digesting gill-edge the cystidia are seen to have become very much reduced in diameter (P1. LI, Fig. I9, zone b). Still nearer to the gill-edge they are seen to have become detached from one gill and to have become partly withdrawn to the other gill, usually to the one from which they originated. Sometimes, however, they can be seen to be broken in two either in the middle or at one end. The cystidia which are just above the zone of spore-discharge are reduced to practically nothing, so that it is difficult or impossible to detect any trace of them.

The disappearance of individual cystidia was observed in a considerable number of instances. Stages in the auto-digestion of six cystidia are shown in Pl. LI, Figs. I3 to 18 . The time which elapsed between the initial shrinking of a cystidium and its total disappearance was found to be less than half an hour. It took ten minutes for the cystidium represented in Fig. I 5 to pass from the fully turgid condition to the final stage shown, and the break in the cystidium represented in Fig. I 6 occurred fourteen minutes after the initial thinning was detected.

One may ask: what becomes of the fluid which is liberated from a cystidium during its auto-digestion? It is possible that part of it simply evaporates, but I think it very probable that much of it is absorbed by the subhymenial cell with which the cystidium is connected and by other cells in its immediate vicinity. At first the cystidium only becomes thinner but retains its form. Probably at first, therefore, the cystidium cell-sap is merely transferred to other cells and the cystidium wall settles down over its diminishing fluid contents. If there were no absorption of the kind I have just suggested, whenever, owing to saturation of the air with water vapour, evaporation was brought to a standstill, the cystidium on its dissolution would form a large drop on the hymenial surface which would surely spread over some of the neighbouring basidia and prevent the liberation of their spores. However, in order to decide quite definitely what becomes of the cystidium products, some further investigations will need to be undertaken.

The disappearance of the cystidia from the gills is so well timed that it seems certain that it is a regulated process. Where the stimulus comes from which acts upon the protoplasm of a cystidium and thus indirectly initiates its auto-digestion, is at present uncertain. Possibly, when a basidium is discharging its spores, it sends out messages to all the cystidia within a certain radius commanding their self-destruction.

The existence of the interlamellar spaces between the gills provides (I) a space in which the basidia of opposing gill-surfaces can develop with- 
out touching one another, and (2) sufficient room for the violent discharge of the spores in the region of spore-discharge. As I have pointed out elsewhere, the spores of all Hymenomycetes, when moist, are very adhesive and, when brought into contact with one another, stick together. If the spores on basidia of opposing gills were to touch one another during development, it is probable that during the subsequent expansion of the pileus they would pull one another off the sterigmata, with the result that later on they would not be properly liberated. However, whilst the spores are ripening, opposing hymenial surfaces are entirely prevented from coming into contact with one another owing to the fact that they are propped apart by the numerous cystidia.

The interlamellar spaces seem to be somewhat too wide, if we are to suppose that their one function is to provide space for the free development of the basidia and spores (cf. Pl. LI, Fig. I9). However, from my studies of the mode of spore-discharge in the Coprini and in the Hymenomycetes generally, it has become clear that the interlamellar spaces require to be sufficiently broad to permit of the spores being violently discharged into them without any risk of their striking and adhering to the opposing gills towards which they are propelled. The spores of Coprimus atramentarius are shot forward from the basidia for an average distance of the order of $0.05 \mathrm{~mm}$. before they begin to fall vertically downwards. Each interlamellar space, in order to permit of successful spore-discharge, must therefore have a minimum width just exceeding $0.0 .5 \mathrm{~mm}$. The actual width of the spaces just exceeds $0.10 \mathrm{~mm}$. It appears probable, therefore, that with the allowance of a slight margin of safety, the width of the interlamellar spaces is reduced to a minimum with due regard to the liberation of the spores. Since the width of the spaces is determined by the length of the cystidia, we may conclude that the length of the cystidia is correlated with the width of the space between the gills required for the violent discharge of the spores in the region of spore-discharge.

From the facts which I have now recorded it seems clear that the cystidia of Coprinus atramentarius are fitted for their prop function by their structure, size, position, number, and early development, whilst the time, order, and mode of their destruction are arrangements which prevent their becoming obstacles to the escape of the spores from the fruit-body. Even if we were to search throughout the whole range of the vegetable kingdom, it would be difficult to find any more beautiful and perfect example of cellular specialization and adaptation of structure to function than is here afforded us,

\section{iII. General Remarks on Coprinus Fruit-bodies.}

It was pointed out in the introductory remarks that whereas Coprinus atramentarins is provided with numerous cystidia on its general gill- 
surfaces, $C$. comatus possesses none in these situations. This marked difference between two fairly closely allied species must now be explained. In Coprinus comatus cystidia are not required on the general surfaces of the gills because the interlamellar spaces are provided for by a structural arrangement which renders unicellular props unnecessary. The gill-margins in this species are considerably swollen, with the result that they are nearly twice as thick as the gill-plates, which alone are covered with the hymenium. ${ }^{1}$ The swollen gill-margins of adjacent gills are in contact with one another before the pileus begins to open out. Owing to the presence of these marginal thickenings, and also owing to a fitting spacial arrangement of the gills where they are attached to the pileus flesh, the gills are kept a sufficient distance apart to provide the requisite interlamellar spaces for the free development of opposing hymenial layers. In Coprimus atramentarius, on the other hand, the gill-margins are no thicker than the other parts of the gills (P1. L, Fig. 5). It is clear that the cystidia of C. atramentarius take the place of the swellings on the gill-margins of $C$. comatus. We may conclude that in the genus Coprinus there are at least two methods of providing for the maintenance of interlamellar spaces: (I) the cystidia method, and (2) the gill-margin method. The former is employed not only by $C$. atramentarius but also by $C$. narcoticus, $C$. stercorarius, $C$. niveus, $C$. fimetarius, and a number of other species, and the latter by $C$. comatus, C. sterquilinus, and C. plicatiloides. ${ }^{2}$

I have examined the fruit-bodies of the following species of Coprinus: C. narcoticus, C. stercorarius, C. niveus, C. lagopus, C. ephemerus, C. fimetarius, and two other species which occur at Winnipeg, and are either identical with or very closely related to $C$.plicatilis and $C$. Friesii respectively, and have found that the cystidia are removed from the gills of all of them at the time of spore-discharge by a process of auto-digestion similar to that which occurs in $C$. atramentarius. It seems very probable that selfdestruction in connexion with spore-liberation is the rule for cystidia wherever they occur in the Coprini.

In $C$. stercorarius, $C$. fimetarius, and $C$. narcoticus the cystidia have just the same functions as in $C$. atramentarius; they stretch across the interlamellar spaces from gill to gill, and keep the thin gills separated both during spore-development and spore-discharge. In C. niveus the cystidia, which are even larger than those of $C$. atramentarius, stretch across the inter-

1 A. H. R. Buller, Researches on Fungi, Pl. I, Fig. 5 and Pl. III, Fig. I4. A thin crosssection, taken through a pileus of $C$. comatus just before it opens out, looks like a wheel: the swollen marginal gill-bands in close apposition form an inner cylinder around the stipe corresponding to the hub, the pileus flesh forms an outer cylinder corresponding to the rim, and the gill-plates held in position between the two cylinders correspond to the spokes.

2 C. plicatiloides, Buller, is apparently a new species. I found it coming up on horse-dung at Winnipeg. Vide Researches on Fungi, p. 69. I hope to give a full description of this species in another publication. 
lamellar spaces during the early stages of the development of the pileus, and at this time serve to keep the gills apart. However, during the expansion of the pileus just before spore-discharge begins, the gills become widely separated, with a consequent increase in the width of the interlamellar spaces. As a result of this the cystidia become too short to stretch across the interlamellar spaces any longer, and when spore-discharge begins, they simply project from the gills from which they have originated, so that their free ends come to be situated at some distance from the opposing gills. It thus appears that in Coprinus niveus the cystidia cease to have any function, and become useless as soon as the pileus begins to open out. In some species, e. g. C. lagopus, most of the cystidia are not long enough to stretch right across the interlamellar spaces. However, they probably serve as guards, so that if by accident during development one gill should approach too near another, the general hymenial surfaces of opposing gills will not come into contact. It is possible that in some species some or all of the cystidia may have become vestigial. A more detailed account of the genus Coprinus I shall reserve for a future publication.

Massee ${ }^{1}$ has stated that 'many species included in Coprinus, as C.plicatilis and others having dry non-deliquescent gills, have no real affinity with this genus'. Whilst dissenting from Massee's view that $C$. plicatilis and its allies should be removed from the genus Coprinus, $\mathrm{I}^{2}$ accepted his implied statement that these species had gills which were non-deliquescent; and $\mathrm{I}^{3}$ further said that there is no auto-digestion in C. plicatiloides. My recent studies have taught me that both Massee and I have been mistaken in supposing that there is no auto-digestion in the small ephemeral species which expand like parasols. I have found that there is a certain amount of auto-digestion at the gill-edges of $C$.plicatiloides, C.plicatilis, ${ }^{3}$ and $C$. ephemerus, which takes place in connexion with spore-liberation in the same general way as in $C$. comatus. In these species the gills split from above downwards, each one becoming $Y$-shaped in cross-section. The autodigestion which takes place is limited to the lower portion of the unsplit part of each gill. It does not begin until the time when spores are about to be liberated, and is so slight that it is not surprising that it has hitherto been overlooked. I have now examined the following species of Coprimus: C. comatus, C. atramentarius, C. sterquilinus, C. fimetarius, C. micaceus, C. narcoticus, C. stercorarius, C. niveus, C. lagopus, C. plicatilis, C. plicatiloides, $C$. ephemerus, and $C$. Friesii, and have found that auto-digestion to a greater or less extent takes place in all of them. These thirteen species are fairly representative of their genus, and until some species

${ }^{1}$ G. Massee, Textbook of Fungi, London, I906, p. 364 .

2 A. H. R. Buller, Researches on Fungi, London, p. 209.

3 Ibid., p. 75 .

${ }^{3}$ Auto-digestion of the cystidia and gill-margins certainly takes place in the form of $C$. plicatilis found at Winnipeg, but possibly this is not true of the somewhat dry English form. 
are found, if such there are, in which there is no auto-digestion whatever, I think we should regard auto-digestion of the gills as one of the most constant and general of all the characters of Coprinus species.

In a former publication I contrasted the Mushroom and the Coprinus types of fruit-bodies as represented by Psalliota campestris on the one hand and by Coprinus comatus on the other. However, since making that contrast, I have realized that it was incomplete. I omitted to mention two quite general and, as it seems to me, fundamental points of difference between the gills of Coprini and of all other Agaricineae, which I have only realized during my more recent and extended studies. In the Coprini the gills are: (I) relatively very thin, and (2) parallel-sided, whereas in fruitbodies of the Mushroom type the gills are: (1) relatively very thick, and (2) have their sides inclined to one another like the sides of a penknife. It seems to me that the extreme reduction in gill-substance in the Coprini has necessitated that the two sides of each gill should be parallel, and it also seems to me that the ripening and discharge of the spores from below upwards on each gill, together with the gradual auto-digestion of the sporefree portions of the gills from below upwards, are special adaptations which permit of successful spore-liberation from parallel-sided gills. In wedgeshaped gills, on the other hand, such as occur in Psalliota campestris, \&c., the two gill-sides look slightly downwards. In this type of gill every square millimetre of gill-surface can successfully shed a certain number of spores every minute (or other unit of time) during the whole period of spore-discharge. Hence with wedge-shaped gills there is no need for the spores to ripen and be discharged in succession from below upwards on each gill, and no need for auto-digestion. A fuller statement and analysis of the facts of the comparative morphology of the Agaricineae in relation to the production and liberation of spores I shall reserve for publication in another place.

\section{APPENDIX.}

Since the above was written, I have had an opportunity of examining some fruit-bodies of Inocybe asterospora. It was observed that the cystidia in this species do not undergo auto-digestion, but remain fixed in the hymenium during the whole time of spore-discharge. In a very small unexpanded fruit-body the cystidia were found to be well developed, although only an occasional basidium had begun to produce its spores. The cystidia stretched only about half-way across the interlamellar spaces, and each one had a mucilage drop at its tip. There seemed to be no evidence that the cystidia acted as props to keep the gills apart, to perform which function their peculiar ventricose shape and excretion appear to render them unfitted. Since the cystidia with their mucilage drops only project about $0.02 \mathrm{~mm}$. beyond the spores on the sterigmata, and since the 
spores are shot forward into the interlamellar spaces for a distance of about O.I mm., it seems clear that the cystidia are here too short to hinder the escape of the spores from between the gills in normally oriented fruit-bodies. The exact function of the cystidia of Inocybe still remains to be elucidated.

\section{Summary of the Chief Results.}

The gills of Coprinus atramentarius are of great width and of extreme thinness, and consequently are very flexible. Numerous long cystidia stretch between and connect adjacent gills, the general surfaces of which thus become separated by an interlamellar space about $0.10 \mathrm{~mm}$. wide. The cystidia serve as props, firstly, to keep the gills from touching one another by their general surfaces during the development of the spores, and, secondly, to provide sufficient interlamellar space for the escape of the spores from between the gills during their discharge.

The cystidia do not drop out of the gills when mature. Their disappearance is due to auto-digestion. Excluding the cystidia, the gills undergo auto-digestion in the manner that I have already described for Coprinus comatus. Each cystidium begins to undergo auto-digestion as soon as it comes to be situated about $0.5 \mathrm{~mm}$. above the upwardly progressing general zone of auto-digestion and about forty minutes or so before the basidia and paraphyses in its immediate vicinity. During their autodigestion the cystidia become progressively thinner, their contents are apparently absorbed by neighbouring cells, and they are finally withdrawn in a much reduced state to the gill-sides, where their destruction is completed.

The cystidia, owing to their early auto-digestion, never persist until the upwardly progressing zone of spore-discharge reaches them. Their propfunction, however, is retained up to the last possible moment, and they disappear just in time to prevent the falling spores from striking and adhering to them.

In the genus Coprinus there are at least two methods of providing for the maintenance of interlamellar spaces: (I) the cystidia method, and (2) the swollen gill-margin method. The former is employed by $C$. atramentarius, C. narcoticus, C. stercorarius, $C$. fimetarius, and C. niveus, and the latter by $C$. comatus, $C$. sterquilinus, and $C$. plicatiloides. The three last-named species do not have cystidia on their hymenial surfaces.

Auto-digestion of the cystidia has been observed in eight species of Coprinus. It seems very probable that self-destruction in connexion with spore-liberation is the rule for cystidia wherever they occur in the Coprini.

Probably, throughout the Coprini, cystidia have a mechanical function in that they serve to prevent opposing hymenial surfaces from touching one another during the development of the basidia and spores. However, if so, this function is carried out in slightly different ways in different species.

A certain amount of auto-digestion occurs in the small coprophilous 
species of Coprinus which open out like parasols, such as C.plicatilis, C.plicatiloides, $C$. ephemerus, and $C$. Friesii. It seems probable that auto-digestion to a greater or less extent, beginning at the gill-edges, is a general character of the Coprini.

In the Coprini the gills are (I) relatively very thin, and (2) parallelsided, whereas in fruit-bodies of the Mushroom type the gills are (I) relatively very thick, and (2) have their sides inclined to one another like the sides of a penknife. In the Coprini the ripening and discharge of the spores from below upwards on each gill, and the gradual auto-digestion of the spore-free portions of the gills from below upwards, are to be regarded as adaptations which permit of successful spore-liberation from parallel-sided gills. In wedge-shaped gills, such as those of Psalliota campestris, there is no need for the spores to ripen and be discharged from below upwards and for autodigestion, since the hymenial surfaces are so arranged in nature that they look slightly downwards.

In Inocybe asterospora the cystidia which excrete drops of mucilage from their free ends do not undergo auto-digestion like those of Coprimus, but persist during the whole period of spore-discharge. They are, however, too short to form obstacles to the escape of the spores in normally oriented fruit-bodies. Their function has not been determined, but does not appear to be a mechanical one.

\section{EXPLANATION OF PLATES L AND LI}

Illustrating Prof. Buller's paper on the Cystidia of Coprinus.

\section{PLATE L.}

Figs. all of Coprimus atramentarius.

Figs. 1-4. Stages in the development of the fruit-body as shown by vertical sections.

Fig. I. Section of a young fruit-body in which the pileus is opening out. The spores, as is indicated by the shading on the gills, are ripening from below upwards. Spore-discharge and autodigestion have not yet begun. The flesh is thin and the gills very broad. $c-d$, the direction in which the section shown in Fig. 5 was cut; $r$, the region from which the piece of gill sketched in Fig. 6 was taken. Natural size.

Fig. 2. Section of another and older fruit-body. The spores are still ripening from below upwards on the gills. Spores are being shed and auto-digestion is taking place along the gill-edge at $a$. The broken lines show the shape and extent of the gills at the moment auto-digestion began. $s$, lower edge of the gill where spore-discharge and subsequently auto-digestion first became active. Natural size.

Fig. 3. Section of a still older fruit-body, the pileus of which has become helmet-shaped through expansion. The gills have now become reduced by auto-digestion to about one quarter of their original size. $a$, edge of gill where spore-liberation and auto-digestion are still in progress. Natural size.

Fig. 4. Section of a fruit-body in the last stage of its development when spore-liberation has ceased. The gills have now entirely disappeared. The central part of the pileus flesh still crowns the stipe. Natural size. 
Fig. 5. Horizontal section, taken in the direction $c-d$ in Fig. I, through the pileus flesh and four gills. $p$, the pileus flesh; $s$, the edges of the gills towards the stipe; $g$, a gap indicating that the central parts of the gills have been left out for convenience of illustration ; $c$, the cystidia which prop the gills apart and thus maintain the interlamellar spaces. Magnified about 57 .

Fig. 6. Surface view of a piece of gill taken from the region $r$ in Fig. I. This drawing shows the distribution of the cystidia and basidia just before the beginning of spore-discharge and autodigestion. $e e$, the oblique free inner edge of the gill bearing marginal cystidia $m ; c c$, cystidia projecting from the gill; $o 0$, places where cystidia from the adjacent gill were in contact with the hymenial surface before the gills were torn apart. Between the cystidia are shown the basidia, each bearing four black spores. Magnified about 103.

Fig. 7. Drawing showing the general appearance of part of a gill-surface, including the gill-edge, after spore-discharge and auto-digestion have begun (cf. Fig. 2). There are five zones running parallel to the oblique gill-edge: (I) $a-a^{\prime}$, zone of basidia with ripe spores. (2) $b-b^{\prime}$, zone of basidia discharging spores into an interlamellar space. The spores are shot off their sterigmata successively, so that in this zone some basidia have three spores left upon them, some two, some one, whilst some have lost them all. (3) $c-c^{\prime}$, zone of basidia which have discharged all their spores. (4) $d-d^{\prime}$, zone of auto-digestion. The basidia and paraphyses are becoming indistinct and gradually liquefied. (5) $e-e^{\prime}$, the liquid film on the gill-edge containing the products of auto-digestion. $p$, position from which a cystidium has been removed by auto-digestion. Magnification 460 .

Fig. 8. Cross-section showing a cystidium stretching across an interlamellar space between two gills and thus separating two opposing hymenial surfaces. Magnification 440.

Figs. 9, 10, and I I. Single cystidia, showing their variation in size and form and the nature of the subhymenial cells to which they are attached. Magnification 440.

Fig. II. A drawing showing the relative sizes and position of a cystidium, a basidium bearing four spores, some paraphyses, and some subhymenial cells. Magnification 440 .

\section{PLATE LI.}

\section{Figs. all of Coprinus atramentarius.}

Fig. I2. An optical section through a cystidium, showing the cell-wall, protoplasm, and vacuoles. Magnified 440 .

Figs. I3-I8 inclusive. The auto-digestion of six cystidia. $a$ in each figure is a fully turgid cystidium just before the beginning of its auto-digestion. $b, c, d$, \&c. show stages in the auto-digestion of each cystidium. The cystidia were observed stretching across interlamellar spaces near the auto-digesting edges of the gills. Figs. $\mathbf{1}_{3}, \mathbf{I}_{4}, 1_{5}$, and 17 show cystidia which became withdrawn to one of the gills. Figs. 16 and 18 show cystidia which, after becoming more and more slender, snapped into two parts; one part became withdrawn to one gill, and the other to the other gill. Fig. I 5 shows the auto-digestion of a cystidium which had been separated whilst still turgid from one of the gills with which it was originally in contact with its rounded apical end. Fig. I 7 shows the auto-digestion of a cystidium which had been separated whilst still turgid from the gill in which it had originated. Its free pointed basal end is shown at $a$. Magnification about 80 .

Fig. 19. Semi-diagrammatic section taken in a perpendicular plane through three gills during spore-discharge and auto-digestion (cf. Fig. 2). Seven zones can be distinguished: $a$, zone in which the cystidia are fully turgid and are propping the gills apart. The basidia bear spores which are nearly ripe. $b$, zone in which the cystidia are disappearing through anto-digestion. The spores are ready for discharge. $c$, zone of ripest spores from which the cystidia have already disappeared. $d$, zone of spore-discharge where cystidia are absent. Spores are being shot out into the interlamellar spaces. Their sporabolas are represented by arrows. $e$, the spore-free zone. $f$, zone of autodigestion where basidia and paraphyses are being destroyed. $g$, the liquid film at the gill-edge containing the products of auto-digestion. $h$, the hymenial layer made up of basidia, paraphyses, and cystidia; $s$, the subhymenial cells; $t$, the trama. $i i$, cystidia which have been torn from the opposite gills by their rounded apical ends. $j j$, cystidia which have been torn from the opposite gills in which they originated so that they are now attached by their apical ends : their contracted bottle-neck-like basal ends are free. $k k$, cystidia which have become very slender owing to autodigestion, but which are still attached to both gills. $l l$, cystidia which are being withdrawn to the gill-sides. $m$, a cystidium which has snapped into two parts. oo, remains of cystidia. Magnification about $\mathrm{x}$ IO. 
Annals of Botany,

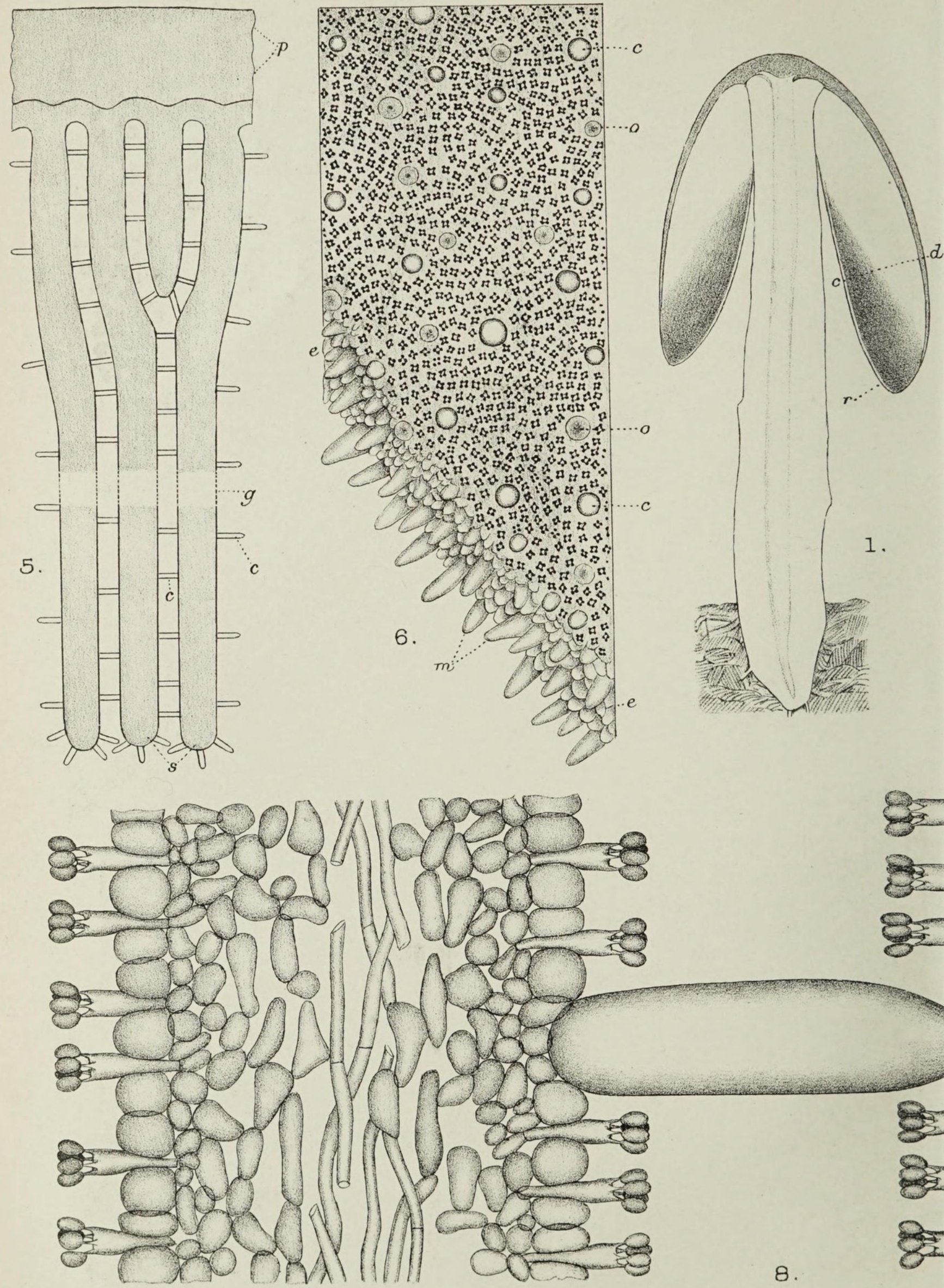

Del. A.H.R. Buller. 


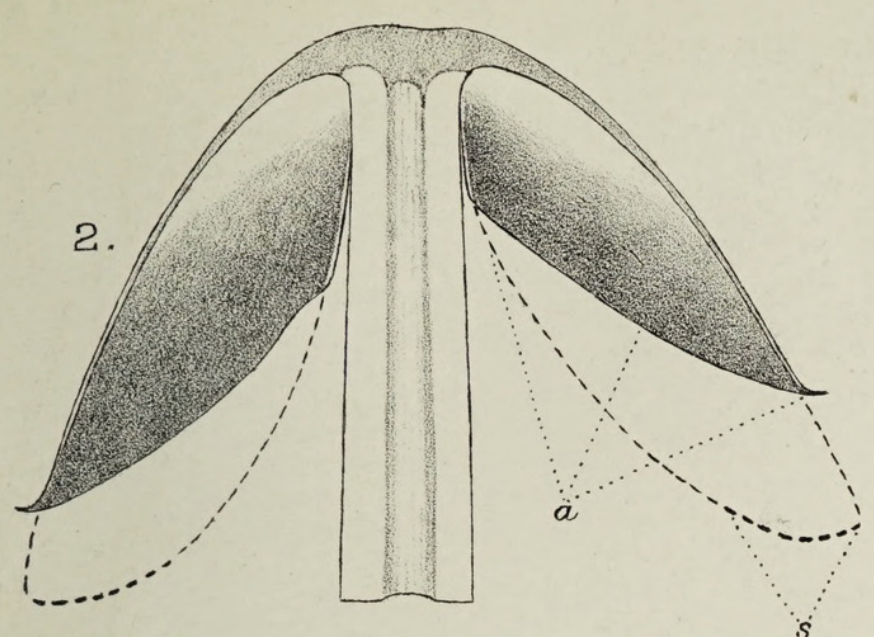

Vol. XXIV, PL.L.
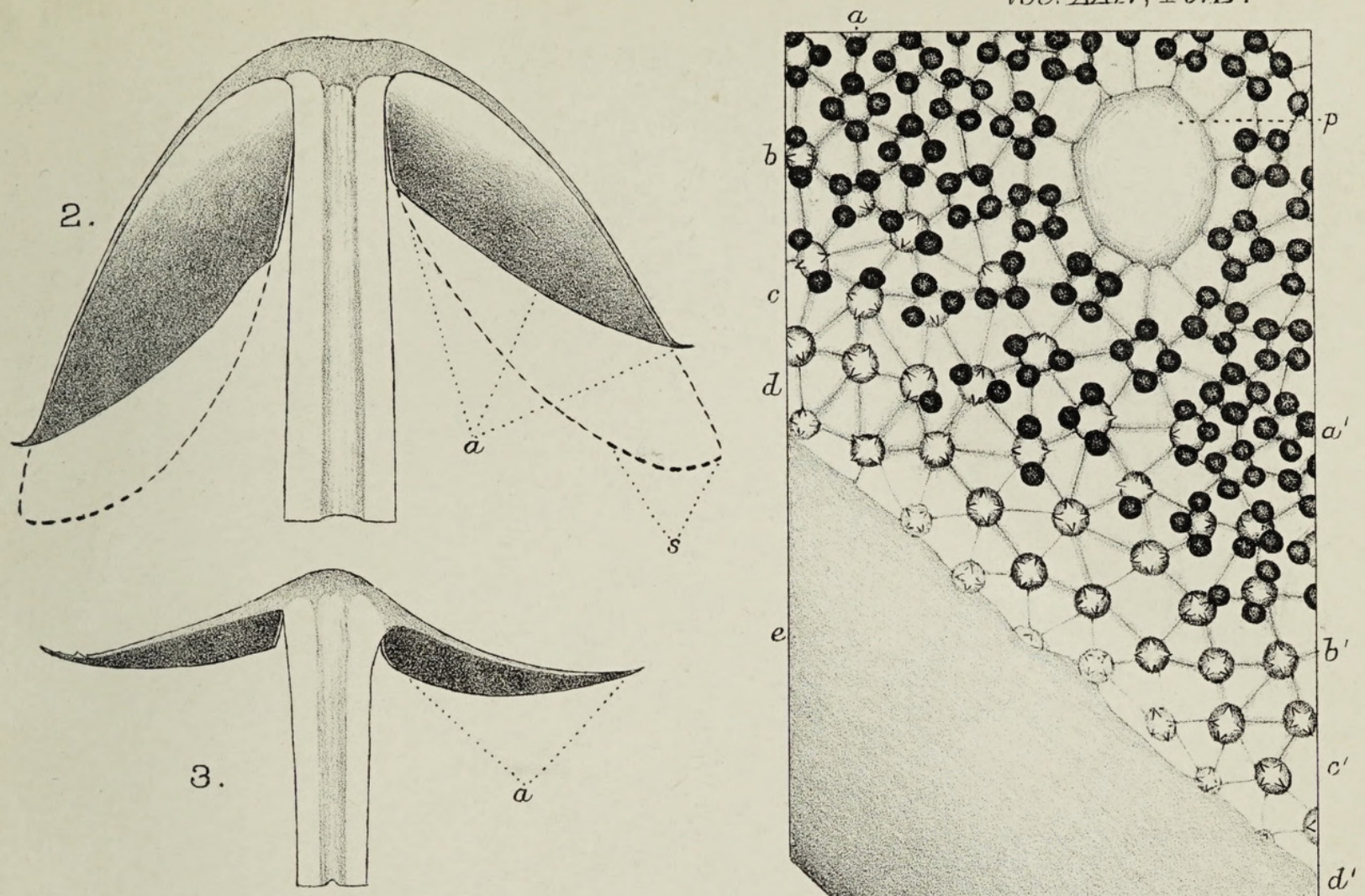

2 a $90 \% 0 \%$
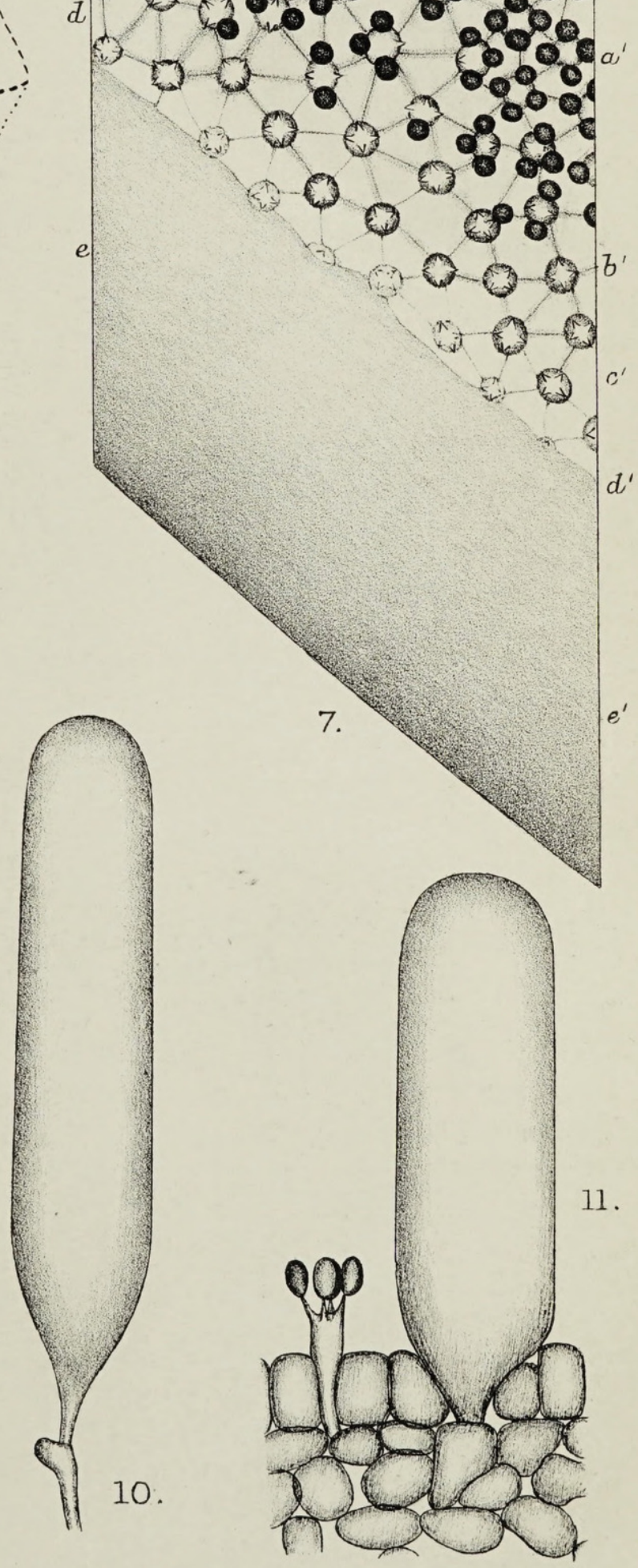

Huth, lith et imp 
Annals of Botany,

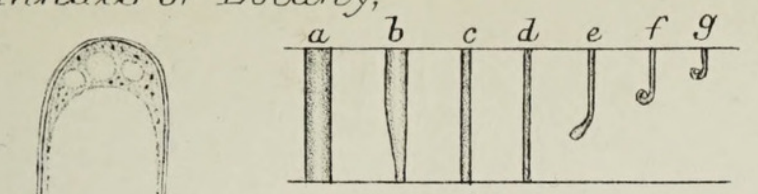

13.

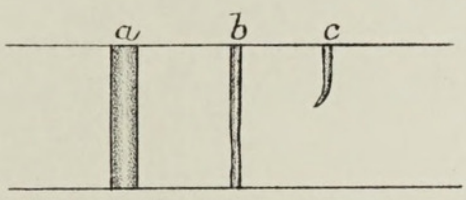

14.

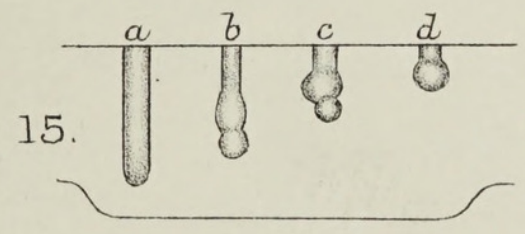

VoZ. XXIV.PZ IIL

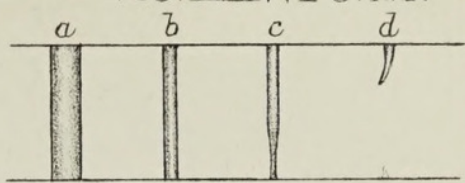

16.

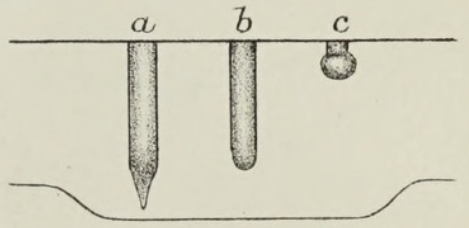

17.

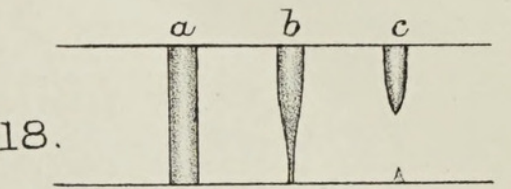

12
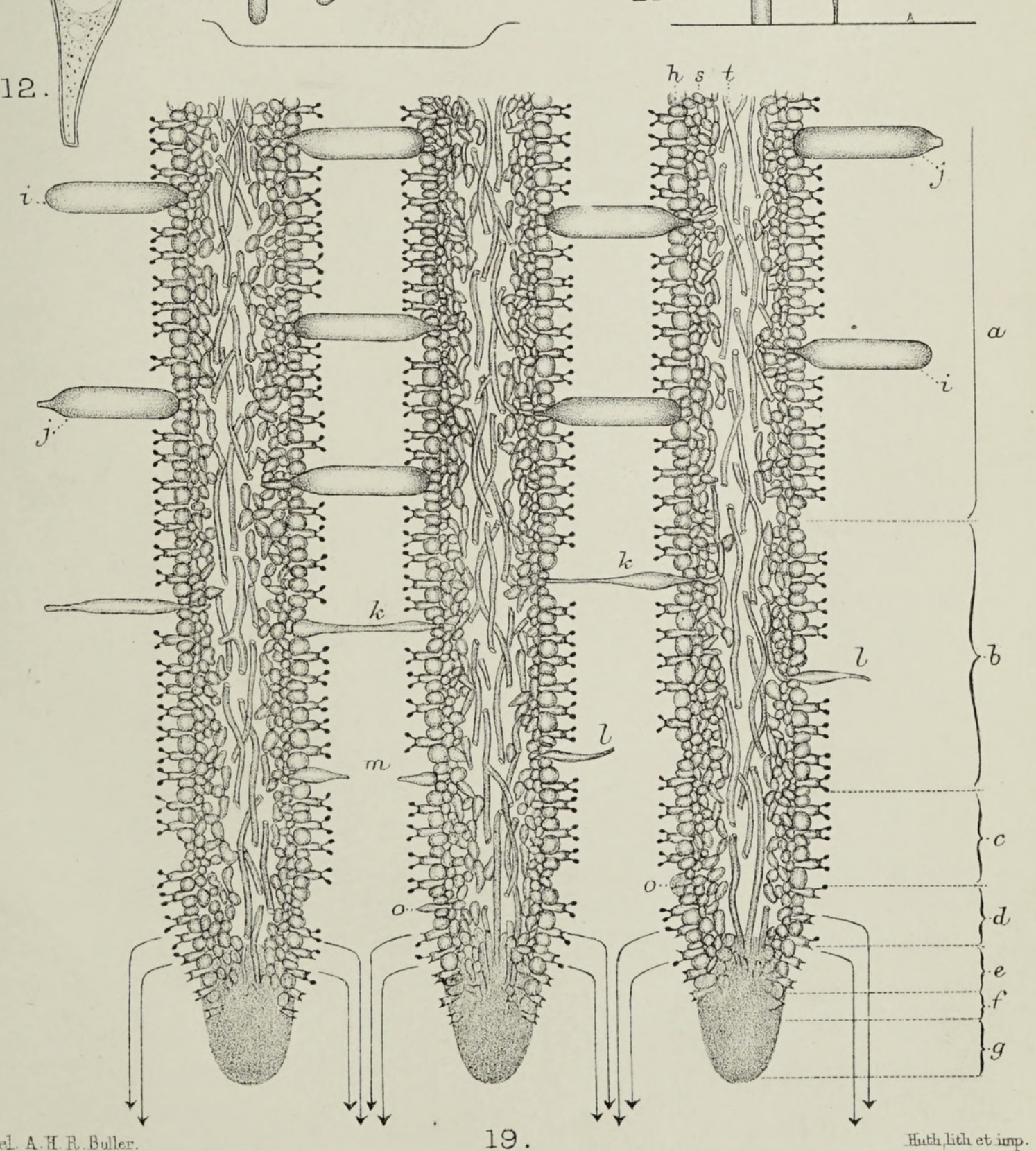

BULLER - ON COPRINUS ATRAMENTARIUS. 


\section{$2 \mathrm{BHL}$ Biodiversity Heritage Library}

Buller, A. H. Reginald. 1910. "The function and fate of the cystidia of Coprinus atramentarius, together with some general remarks on Coprinus fruit-bodies." Annals of botany 24, 613-629.

https://doi.org/10.1093/oxfordjournals.aob.a089294.

View This Item Online: https://www.biodiversitylibrary.org/item/262605

DOI: https://doi.org/10.1093/oxfordjournals.aob.a089294

Permalink: https://www.biodiversitylibrary.org/partpdf/319802

\section{Holding Institution}

New York Botanical Garden, LuEsther T. Mertz Library

\section{Sponsored by}

BHL-SIL-FEDLINK

\section{Copyright \& Reuse}

Copyright Status: Public domain. The BHL considers that this work is no longer under copyright protection.

This document was created from content at the Biodiversity Heritage Library, the world's largest open access digital library for biodiversity literature and archives. Visit BHL at https://www.biodiversitylibrary.org. 